\title{
Long non-coding RNA linc-ITGB1 promotes cell proliferation and migration in human hepatocellular carcinoma cells
}

\author{
MEILING SHANG, XINHUA XU, MIN ZHANG and HONGYUAN YANG \\ Department of Infectious Disease, Weifang People's Hospital, Weifang, Shandong 261000, P.R. China \\ Received January 14, 2016; Accepted March 23, 2017
}

DOI: 10.3892/etm.2017.5143

\begin{abstract}
Hepatocellular carcinoma (HCC) represents a major endpoint of chronic liver diseases and is the third leading cause of cancer-related mortality. Long intergenic non-coding RNA-integrin subunit $\beta 1$ ITGB1 (linc-ITGB1) is a novel long non-coding RNA, which is implicated in the development and progression of human tumors. However, its involvement in hepatocarcinogenesis remains to be elucidated. In the present study, the specific roles of linc-ITGB1 on cell proliferation and metastasis in HCC were investigated. It was initially observed that the expression of linc-ITGB1 was significantly elevated in 30 cases of clinical HCC tissues relative to their adjacent non-cancerous tissues. Expression of linc-ITGB1 was particularly elevated in the highly invasive cell line, HCCLM3. Knockdown of linc-ITGB1 in HCCLM3 cells using a specific short hairpin RNA decreased cell viability and colony formation in vitro. In addition, cell cycle analysis demonstrated that linc-ITGB1-depleted cells accumulated in the G0/G1 phase. HCCLM3 cells with linc-ITGB1 depletion exhibited significantly decreased migration and invasion abilities, when compared with control cells $(\mathrm{P}<0.05)$. These data suggest that linc-ITGB1 promotes HCC progression by inducing cell-cycle arrest. Therefore, targeted therapy against linc-ITGB1 may be a novel strategy to treat $\mathrm{HCC}$.
\end{abstract}

\section{Introduction}

Hepatocellular carcinoma (HCC) is a common liver cancer; a previous report demonstrated that it is the third most frequent cause of cancer-related mortality worldwide (1). The incidence of HCC has increased markedly in previous years, due to the increasing incidence of viral infections, including hepatitis $\mathrm{B}$ and $\mathrm{C}$, in addition to other causes of cirrhosis, such as alcohol abuse (2-4). Therapeutic strategies

Correspondence to: Dr Hongyuan Yang, Department of Infectious Disease, Weifang People's Hospital, 151 Guangwen Street, Weifang, Shandong 261000, P.R. China

E-mail: hongyuanyang9810@sina.com

Key words: linc-ITGB1, hepatocellular carcinoma, proliferation, migration, invasion for this malignancy include surgical hepatic resection or liver transplantation. However, the overall 5-year survival rate remains only $\sim 5 \%$ (5). It is currently understood that $\mathrm{HCC}$ is an epithelial tumor with its origin from mature hepatocytes or stem cells (6). Hepatocarcinogenesis has been considered a multistep process involving different genetic alterations that ultimately lead to malignant transformation (7). Therefore, an improved understanding of the molecular pathways involved in the development and progression of HCC may identify novel therapeutic strategies to improve the treatment of this malignancy.

Previously, advances have been made in the research and identification of regulatory RNA families, particularly those of long non-coding RNAs (lncRNAs), which are currently defined as transcripts of $>200$ nucleotides without evident protein coding capacity $(8,9)$. In previous research, IncRNAs have served as key components of the address code, allowing genes, chromosomes and protein complexes to be trafficked to their destinations subject to activation or deactivation (8). Mounting evidence has established the association between lncRNAs and tumorigenesis (10). HOTAIR, for example, is one common IncRNA that has been reported to reprogram the chromatin state to promote cancer metastasis (11). Another non-protein coding lncRNA, growth arrest specific 5, has been reported to regulate breast cancer cell apoptosis (12). In addition, lncRNAs have also emerged as potential diagnostic or prognostic biomarkers for a number of human malignancies, including lung, breast and colon cancer (13-15).

Notably, lncRNAs comprise natural antisense transcripts and long intergenic non-coding RNAs (lincRNAs). LincRNAs, originating from the intergenic regions of certain genes, function as competitive endogenous RNAs and sequester miRNAs (hence the term 'miRNA sponges') (16), and target chromatin modification complexes or RNA-binding proteins to alter gene expression (17). Previous evidence has revealed that lincRNAs have notable roles in multiple stages of cancer progression (18). The first identified lincRNA, HOTAIR, has been demonstrated to promote metastasis in breast cancer (11), and has a prognostic role and exhibits oncogenic activity in pancreatic cancer (19). Another lincRNA, integrin subunit $\beta 1$ (ITGB1; linc-ITGB1), has recently been a focus of investigation. It was demonstrated that linc-ITGB1 was aberrantly expressed in breast and gallbladder cancer. A knockdown of linc-ITGB1 by short hairpin RNA (shRNA) significantly inhibited cell migration and invasion abilities in breast and 
gallbladder cancer $(20,21)$. These data suggest that linc-ITGB1 may be critically involved in the progression of human cancer. However, the implication of linc-ITGB1 in other types of solid tumors, such as HCC, remains largely unknown.

The current study aimed to investigate the role of linc-ITGB1 in cell proliferation and migration in $\mathrm{HCC}$ cells. A specific shRNA against linc-ITGB1 (shlinc-ITGB1) was synthesized and employed to deplete the expression of linc-ITGB1 in HCC cells. The effects of linc-ITGB1 knockdown on cell proliferation and migration were examined using Cell Counting Kit- 8 and Transwell assays, respectively. The results of the present study suggest that linc-ITGB1 has a pro-oncogenic activity in HCC. Thus, the findings of the current study may provide a novel insight into the diagnosis and treatment of HCC.

\section{Materials and methods}

Patient samples. A total of 30 patients $(45 \pm 5$ years old; male: female, 18:12) with liver cancer were included in the present study. The patients had never received any radiotherapy or chemotherapy. Liver cancer tissues and their adjacent non-cancerous normal tissues were collected from Weifang People's Hospital (Weifang, China). The tissues were frozen with liquid nitrogen immediately. The current study was approved by the Ethical Committee of Weifang People's Hospital. Full informed consent to participate in the study was obtained from all patients.

Cell culture and shRNA infection. The human liver cancer cell lines, MHCC97-L, MHCC97-H and HCCLM3, were purchased from the Shanghai Institute of Cell Biology, (Shanghai, China) and cultured in Dulbecco's modified Eagle's medium (DMEM, Gibco; Thermo Fisher Scientific, Inc., Waltham, MA, USA) supplemented with $10 \%$ fetal bovine serum (FBS; Gibco; Thermo Fisher Scientific, Inc.). All cell culture was maintained at $37^{\circ} \mathrm{C}$ and $5 \% \mathrm{CO}_{2}$ in a humidified incubator. The specific shRNA against human Linc-ITGB1 was designed and chemically synthesized by Invitrogen (Thermo Fisher Scientific, Inc.). The sequence was as follows: 5'-GCAGCTGTTTCCAGAATATTGCTC GAGCAATATTCTGGA AACAGCTGC-3' and control sequence: 5'-GCGGAGGGTTTGAAAGAATATCTCGAG ATATTCTTTCAAACCCTCCGCTTTTTT-3'. Using this shRNA, construction of a lentivirus-delivered short hairpin RNA against Linc-ITGB1 was completed by Shanghai GenePharma, Co., Ltd. (Shanghai, China). For lentivirus infection, HCCLM3 cells were seeded into a 6 -well plate $\left(5 \times 10^{4}\right.$ cells per well) and infected with the lentivirus at a multiplicity of infection of 50. Following $96 \mathrm{~h}$ of incubation at $37^{\circ} \mathrm{C}$, fluorescence microscopy was used to examine the infection efficiency by calculating the percentage of red fluorescence protein-positive cells. For nuclear analysis, staining was performed using 4',6-diamidino-2-phenylindole dye (Beyotime Institute of Biotechnology, Dalian, China) for $10 \mathrm{~min}$ at room temperature at a dilution of 1:1,000.

Reverse transcription-quantitative polymerase chain reaction $(R T$ - $q P C R)$. Whole RNA from human tissues and cultured liver cancer cells were extracted using TRIzol reagent (Takara
Biotechnology, Co., Ltd., Dalian, China) following the manufacturer's protocol. The concentration and quality of each sample were measured by reading the absorbance at 260 and $280 \mathrm{~nm}$ with a Nanodrop 2000 (Thermo Fisher Scientific, Inc.). RNA was purified using the TRIzol reagent (Thermo Fisher Scientific, Inc.) according to the manufacturer's protocol and then PrimeScript RT Master Mix (Perfect Real Time; Takara Biotechnology, Co., Ltd.) was used to obtain the first-strand cDNAs. PCR was performed in an ABI PRISM 7900 Sequence detection system (Applied Biosystems; Thermo Fisher Scientific, Inc.) with the SYBR Premix Ex Taq kit (Takara Biotechnology, Co., Ltd.). The thermocycling conditions were as follows: $95^{\circ} \mathrm{C}$ for $5 \mathrm{~min}$, followed by 40 cycles of $95^{\circ} \mathrm{C}$ for $15 \mathrm{sec}$ and $60^{\circ} \mathrm{C}$ for $30 \mathrm{sec}$. The primers of each gene included were as follows: Lnc-ITGB1, forward 5'-CCTCTCAGCCTC CAGCGTTG-3' and reverse 5'-TGCTCTTGCTCACTCACA CTCC-3'; and GAPDH (internal control), forward 5'-ATGTCT TTCCGTGTTCCTACTGT-3' and reverse 5'-TTTCCCTCA GACTCCTCCTTG-3'. All quantitative data were normalized to GAPDH using the $2^{-\Delta \Delta C q}$ method (22).

Cell proliferation assay. A Cell Counting Kit-8 (CCK-8) assay (Beyotime Institute of Biotechnology) was performed to evaluate the proliferation ability of liver cancer cell line HCCLM3 with and without administration of specific shRNAs against Linc-ITGB1 (shLinc-ITGB1). In total, $2 \times 10^{3}$ HCCLM3 cells were seeded into 96-well plates and cultured for $12 \mathrm{~h}$. Cells were then treated with either the control shRNA or shLinc-ITGB1 $(20 \mathrm{nM})$ and incubated at $37^{\circ} \mathrm{C}$ for another $72 \mathrm{~h}$. Cell viability was determined within five consecutive days using MTT solution (Beyotime Institute of Biotechnology). On each monitored day, $2 \mathrm{mg} / \mathrm{ml}$ of MTT reagent was added into each well prior to another $4 \mathrm{~h}$ incubation at $37^{\circ} \mathrm{C}$. Following this incubation, culture medium was discarded and $200 \mu \mathrm{l}$ of dimethyl sulfoxide was added to each well. The plates were then agitated for $5 \mathrm{~min}$ and the optical density was obtained at an absorbance of $570 \mathrm{~nm}$ with a micoplate reader (Tecan Group Ltd., Männedorf, Switzerland).

Colony formation assay. HCCLM3 liver cancer cells (2,000 cells/well) were pretreated with specific shRNA against Linc-ITGB1, resuspended in $2 \mathrm{ml}$ of $0.4 \%$ agarose solution and DMEM/F12 or F12 culture medium (Gibco; Thermo Fisher Scientific, Inc.) and overlaid onto a $0.8 \%$ bottom agar layer in 6-well plates. The plates were incubated at $37^{\circ} \mathrm{C}$ for 3 to 6 weeks and colonies were calculated by counting the number of colonies $>80 \mu \mathrm{m}$ in diameter. All separate experiments were repeated at least three times in triplicate to obtain the mean and standard deviations on the basis of the colony counts.

Cell cycle determination by flow cytometry. The culture medium was discarded from a sample of $4 \times 10^{5}$ HCCLM3 liver cancer cells. Cells were washed with phosphate-buffered saline (PBS) twice prior to digestion with a Trypsin/EDTA solution. Following this, cells were incubated at $37^{\circ} \mathrm{C}$ in an incubator containing $5 \% \mathrm{CO}_{2}$ until they were detached from the surface of the plate $(\sim 1 \mathrm{~min})$. The cells collected were scattered with PBS and subsequently gathered by low-speed centrifugation $\left(840 \mathrm{xg}\right.$ for $5 \mathrm{~min}$ at $\left.4^{\circ} \mathrm{C}\right)$. Cells were mixed with $70 \%$ ice-cold alcohol and stored at $-20^{\circ} \mathrm{C}$ overnight. The 
mixture was then centrifuged $\left(840 \times \mathrm{g}\right.$ for $5 \mathrm{~min}$ at $\left.4^{\circ} \mathrm{C}\right)$ and the alcohol solution was removed to obtain the cell pellet. Following resuspension in PBS, $0.1 \%$ Triton- $100,4 \mathrm{mg} / \mathrm{ml}$ of RNase A (Beyotime Institute of Biotechnology) and $2 \mathrm{mg} / \mathrm{ml}$ of propidium iodide (PI) were added into the cells. Cells were then incubated at room temperature in the dark for $30 \mathrm{~min}$, a 35-micron nylon mesh was included to filter the cell suspension. A flow cytometry instrument (Beckman Coulter, Inc., Brea, CA, USA) and cell cycle analysis software (Modfit Version 4.0; Verity Software House, Topsham, ME, USA) were used to analyze the cell cycle distribution in HCCLM3 liver cancer cells, according to the manufacturers' protocols.

Transwell assay. Migration and invasion assays were performed in triplicate with a chemotaxis chamber $(8-\mu \mathrm{m}$ pore size; Corning Inc., Corning, NY, USA). HCCLM3 cells were administered shRNAs $48 \mathrm{~h}$ prior to harvest and resuspended in DMEM culture medium without any FBS. A total of $1 \times 10^{4}$ cells $(\sim 200 \mu \mathrm{l})$ were seeded into the upper chambers and lower chambers were filled with $600 \mu \mathrm{l}$ DMEM media supplied with $10 \%$ FBS. Following $12 \mathrm{~h}$ of free migration, the membrane was fixed with cold $100 \%$ methanol $\left(15 \mathrm{~min}, 4^{\circ} \mathrm{C}\right)$ and stained with crystal violet for $5 \mathrm{~min}$. Cells were quantified by using a light microscope (magnification, $\mathrm{x} 200$ ) to count cells that had migrated through the membrane. For the invasion assay, the membrane of the chamber was coated with a Matrigel solution (Corning Inc.) $6 \mathrm{~h}$ prior to the experiment in a $37^{\circ} \mathrm{C}$ incubator. Cells were allowed to invade for $12 \mathrm{~h}$ prior to staining by crystal violet. All procedures were repeated in triplicate.

Statistical analysis. SPSS 19.0 software (IBM Corp., Armonk, NY, USA) was used for statistical analysis. All results are presented as the mean + standard deviation. Student's t-test was performed to determine whether differences between groups were significant. Each experiment was repeated at least three times in triplicate. $\mathrm{P}<0.05$ was considered to indicate a statistically significant difference.

\section{Results}

Linc-ITGBl is highly expressed in HCC tissues and in the invasive HCC cell line. Initially, the expression of linc-ITGB1 in clinical HCC tissues was assessed by RT-qPCR. It was demonstrated that the relative transcription level of linc-ITGB1 in cancerous tissues were significantly increased (4-fold) compared with their paired adjacent non-cancerous tissues (Fig. 1A; $\mathrm{P}<0.05$ ). Furthermore, three increasingly invasive HCC cell lines (MHCC97-L, MHCC97-H and HCCLM3) were cultured. It was demonstrated that the relative transcription level of linc-ITGB1 was the highest in the most invasive HCCLM3 cells, while the least expression of linc-ITGB1 was observed in the least invasive cell line, MHCC97-L (Fig. 1B), indicating that a high expression of linc-ITGB1 was associated with invasiveness in HCC. These observations suggest that linc-ITGB1 is overexpressed in HCC tissues.

Specific shRNA against linc-ITGB1 is effective to knockdown the expression of linc-ITGB1 in HCCLM3 cells. Specific shRNAs against linc-ITGB1 (shLinc-ITGB1) were synthesized
A
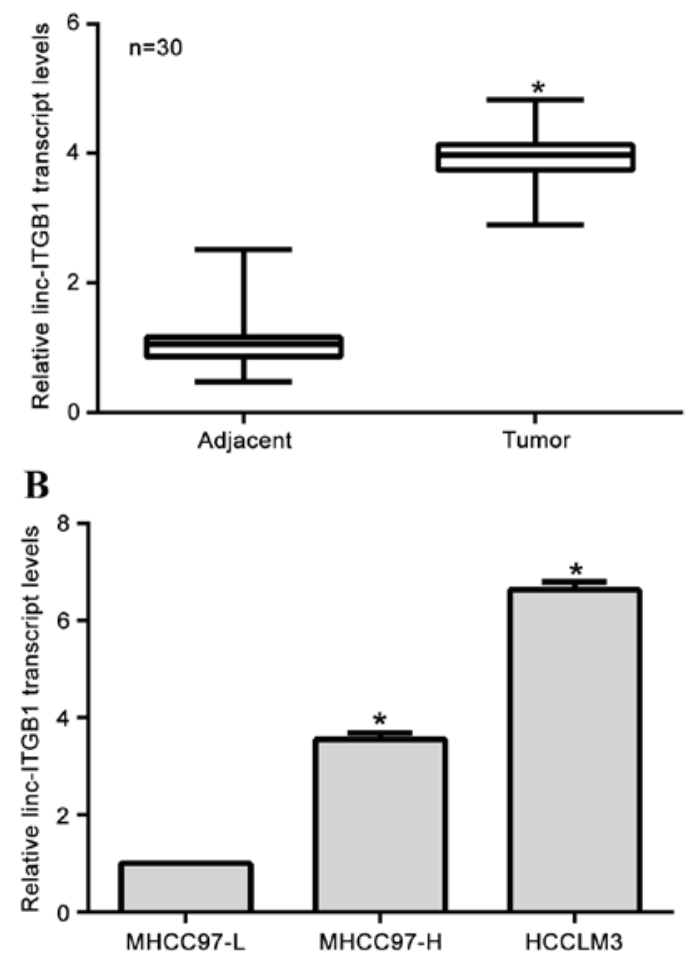

Figure 1. Linc-ITGB1 is highly expressed in HCC tissues and in invasive HCC cell line. (A) Relative transcript levels of linc-ITGB1 in HCC cancerous-tissues $(n=30)$ and adjacent non-cancerous tissues $(n=30)$, as assessed by reverse transcription-quantitative polymerase chain reaction. (B) Expression of linc-ITGB1 in cultured HCC cell lines, MHCC97-L, MGCC97-H and HCCLM3, as detected by reverse transcription-quantitative polymerase chain reaction. The order of invasiveness of the three cell lines was from lowest to highest: MHCC97-L, MHCC97-H and HCCLM3. "P<0.05 vs. shNC. Linc-ITGB1, long intergenic non-coding RNA-integrin subunit $\beta 1$; $\mathrm{HCC}$, hepatocellular carcinoma.

to deplete the expression of linc-ITGB1 in HCCLM3 cells. The HCCLM3 cell line was selected because it exhibited the highest expression of linc-ITGB1 (Fig. 1B). Following transfection of shLinc-ITGB1, it was observed that the majority of cells (90\%) exhibited red fluorescence (Fig. 2A), indicating a high efficiency of transfection. Total RNA was then isolated and it was further detected that the transcript level of linc-ITGB1 was significantly depleted by up to $60 \%$ in shLinc-ITGB1-transfected cells $(\mathrm{P}<0.05)$, while control shRNA-transfected cells demonstrated almost no change in linc-ITGB1 expression (Fig. 2B). These data suggest that synthesized shRNA is effective at depleting the expression of linc-ITGB1.

Knockdown of linc-ITGB1 inhibits cell proliferation and colony formation in vitro. Using shLinc-ITGB1, the effects of linc-ITGB1 knockdown on cell growth in vitro were assessed. Following the CCK- 8 assay, there was no significant difference in cell proliferation observed among the three groups for the first 2 days. However, cell proliferation in the shLinc-ITGB1-transfected HCCLM3 cells was significantly reduced from the third day (Fig. 3A; $\mathrm{P}<0.05$ ). Cell viability was significantly inhibited in the shLinc-ITGB1 group when compared with either control or scramble shRNA (shNC) 
A

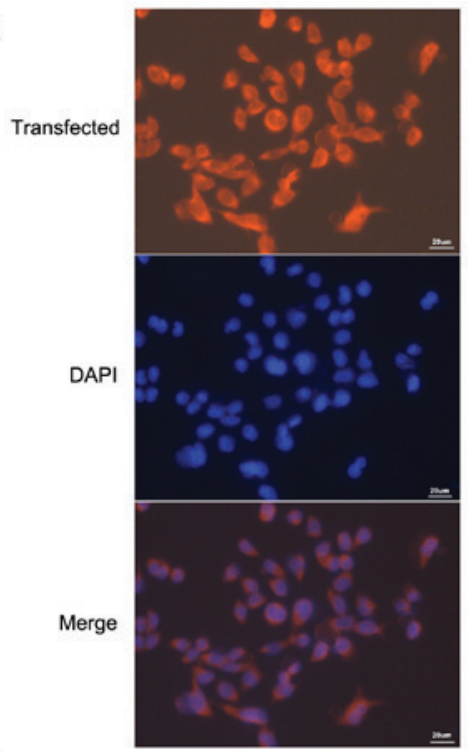

B

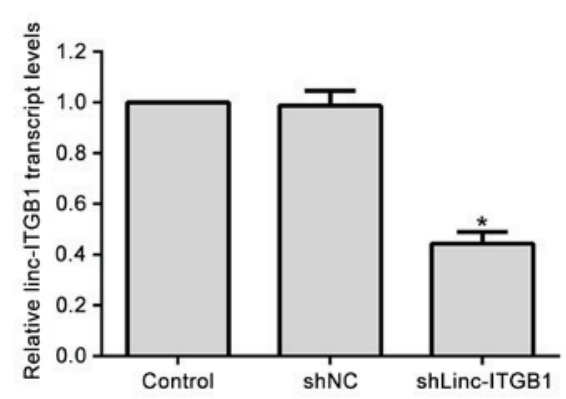

Figure 2. Specific shRNA against linc-ITGB1 is effective at knocking down the expression of linc-ITGB1 in HCCLM3 cells. (A) Following transfection of the specific shRNA, cells from control and shLinc-ITGB1 groups were observed under a fluorescence microscope (magnification, x200). It was demonstrated that $290 \%$ of shLinc-ITGB1-transfected cells exhibited red fluorescence which suggests a high transfection efficiency. Scale bar $=20 \mu \mathrm{m}$. (B) Total RNAs were collected from distinct groups of cells. The relative transcript level of linc-ITGB1 was analyzed using reverse transcription-quantitative polymerase chain reaction. " $\mathrm{P}<0.05$ vs. shNC. linc-ITGB1, long intergenic non-coding RNA-integrin subunit $\beta 1$; shRNA, short hairpin RNA; linc-ITGB1, long intergenic non-coding RNA-ITGB1; shNC, scramble negative control shRNA.

group (Fig. 3A; $\mathrm{P}<0.05$ ). Colony formation ability was assessed by counting the colonies and it was demonstrated that the control and shNC groups exhibited a similar colony formation ability, by forming an equal amount of 140 colonies. However, in the shLinc-ITGB1 group, only 62 colonies were counted, which is a significant $57.4 \%$ decrease compared with its counterpart (Fig. 3B; $\mathrm{P}<0.05$ ). These data suggest that knockdown of linc-ITGB1 significantly eliminates the cell proliferative and colony forming abilities of the highly invasive HCCLM3 cells.

Knockdown of linc-ITGB1 arrests cell cycle in G0/G1 phase in HCCLM3 cells. To explain the inhibited cell proliferation by knockdown of linc-ITGB1, cell cycle progression was analyzed. The percentage of cells in each phase was quantified. It was demonstrated that control and shNC cell groups had a similar percentage of cells in each phase (G0/G1, S and G2/M phase; Fig. 3C). However, in the shLinc-ITGB1 group, cells in the G0/G1 phase were significantly increased, with the
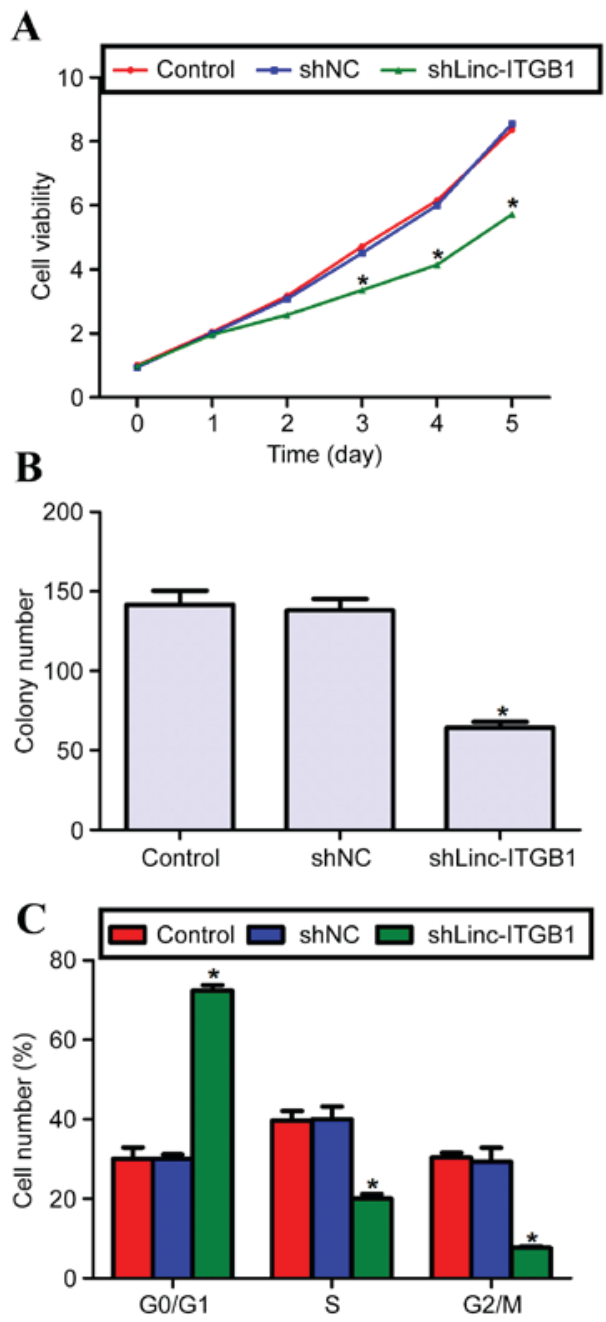

Figure 3. Knockdown of linc-ITGB1 inhibits cell proliferation and colony formation and arrests cell cycle in the G0/G1 phase in HCCLM3 cells. (A) A Cell Counting Kit-8 assay was conducted to assess the effects of linc-ITGB1 knockdown on cell proliferation in HCCLM3 cells. Cell viability was determined by reading the optical density values of each well for five consecutive days. (B) Colony formation was assessed following crystal violet staining. The colonies were counted and results are presented in a histogram. (C) Cell cycle progression was analyzed using flow cytometry. The percentage of cells in each phase of the cell cycle was quantified. Cells of the shLinc-ITGB1 group significantly accumulated in the G0/G1 phase, thus the percentage of cells in the $\mathrm{S}$ and $\mathrm{G} 2 / \mathrm{M}$ phases were significantly decreased. " $\mathrm{P}<0.05$ vs. shNC. Linc-ITGB1, long intergenic non-coding RNA-integrin subunit $\beta 1$; shLinc-ITGB1, shRNA against linc-ITGB1; shNC, scramble negative control shRNA.

cell percentage as high as $72 \%$ in this phase (compared with $\sim 30 \%$ in the control group; Fig. 3A; $\mathrm{P}<0.05)$. Accordingly, the percentage of cells in $\mathrm{S}$ or $\mathrm{G} 2 / \mathrm{M}$ phase was significantly decreased in the shLinc-ITGB1 group (Fig. 3C; $\mathrm{P}<0.05$ ). These data suggest that cell cycle progression is arrested by a knockdown of linc-ITGB1 in HCCLM3 cells.

Knockdown of linc-ITGB1 inhibits cell migration and invasion in HCCLM3 cells. In the three cultured cell lines, HCCLM 3 cells exhibited the highest invasive ability. To assess the effects of linc-ITGB1 knockdown on cell migration and invasion, HCCLM3 cells were further cultured and transfected with shLinc-ITGB1. Following $12 \mathrm{~h}$ of free migration, cells were stained with crystal violet. Images of three randomly 

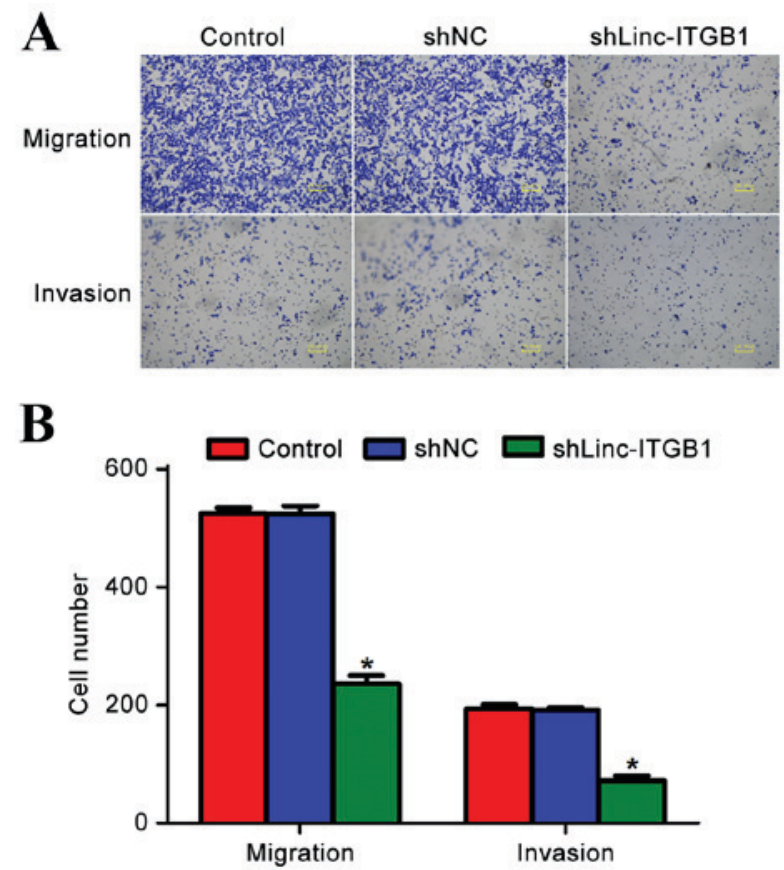

Figure 4. Knockdown of linc-ITGB1 inhibits cell migration and invasion in HCCLM3 cells. (A) HCCLM3 cells transfected with or without linc-ITGB1 were subjected to migration and invasion assays. For the invasion assay, an additional Matrigel was coated to the upper surface of the chamber Following $12 \mathrm{~h}$ of free migration, cells transmigrating to the lower surface of the chamber were stained with crystal violet and imaged. Magnification, x200. Scale bar, $100 \mu \mathrm{m}$. (B) From the three randomly selected fields under microscopy, cells in the lower surface of the chamber were counted and averaged in the migration and invasion assays. Data are presented as a histogram for the migration and invasion assays. ${ }^{*} \mathrm{P}<0.05$ vs. shNC. Linc-ITGB1, long intergenic non-coding RNA-integrin subunit $\beta 1$; shNC, scramble negative control shRNA.

selected fields were captured (Fig. 4A). Transmigrated cells were counted and the cell number of each group is presented in Fig. 4B. In the migration assay, $\sim 500$ cells migrated to the lower surface of the chamber in the control or shNC group. However, only an average of 214 linc-ITGB1-depleted cells successfully migrated, a significant $57.2 \%$ decrease compared with control cells $(\mathrm{P}<0.05)$. Similarly, in the invasion assay, $\sim 200$ cells invaded through the Matrigel in the control or shNC group. However, only $\sim 70$ cells invaded through the Matrigel coat to the lower surface of the chamber (Fig. 4B; $\mathrm{P}<0.05$ ). These observations indicate that knockdown of linc-ITGB1 significantly inhibits cell migration and invasion abilities in HCCLM3 cells $(\mathrm{P}<0.05)$.

\section{Discussion}

HCC is a prevalent primary malignancy characterized by aggressive invasion, early metastasis and resistance to existing chemotherapeutics (1). Despite an increase in the 5-year survival rate, certain patients suffering from HCC remain threatened by poor prognosis due to the aggressive growth and metastasis of $\mathrm{HCC}(23,24)$. Thus, a further understanding of the molecular mechanisms underlying the progression and metastases of HCC may improve the current therapy (25).

IncRNA has emerged as a key component of the address code allowing genes, chromosomes and protein complexes to be trafficked to their destinations and be subjected to activation or deactivation (8). Mounting evidence has established the implication of lncRNAs in tumorigenesis (10). LincRNA are a class of lncRNA that are currently receiving wide attention from researchers worldwide. The first identified lincRNA, HOTAIR, has been demonstrated to promote metastasis in breast cancer (11), serve a progrostic role and exhibit oncogenic activity in pancreatic cancer (19). Notably, linc-ITGB1 has been demonstrated to promote cell migration and invasion in breast and gallbladder cancer $(20,21)$. The present study initially confirmed that expression of linc-ITGB1was significantly elevated in HCC tissues compared with their matched adjacent non-cancerous tissues. The overexpression of linc-ITGB1 in HCC tissues was consistent with previous studies that reported the aberrantly increased expression of linc-ITGB1 in breast and gallbladder cancer $(20,21)$. Furthermore, in the present study it was observed that the expression of linc-ITGB1 was positively correlated with cell invasiveness, as indicated by the finding that the most invasive HCCLM3 exhibited the highest transcript level of linc-ITGB1. This observation indicated that linc-ITGB1 may be associated with aggressive invasion in HCC.

Therefore, the present study modified the expression of linc-ITGB1 using a specific shRNA in HCCLM3 cells. It was observed that knockdown of linc-ITGB1 significantly inhibited tumor cell growth in the proliferation assay and colony formation assay. The proliferation assay using CCK-8 is useful for assessing cell viability in an adhesion condition, while colony formation assay is a convenient tool to assess cell growth ability in anchorage-independent condition and is closely associated to the in vivo situation $(26,27)$. Suppression of cell proliferation by shLinc-ITGB1 in both adhesion presence and anchorage-independent conditions suggests that linc-ITGB1 has a critically positive role in promoting tumor growth in HCC. Furthermore, it was observed that depletion of linc-ITGB1 also decreased cell migration and invasion abilities. The name linc-ITGB1 suggests that this intergenic lincRNA is potentially co-regulated with B1-integrin, which is also a pro-migration gene (20). Promotion of cell migration and invasion by linc-ITGB1 has already been observed in breast and gallbladder cancer models $(20,21)$. Thus, it would not be noteworthy that knockdown of linc-ITGB1 also suppressed cell migration and invasion in HCCLM3 cells. The results of the present study suggest that linc-ITGB1 exhibits a critical role in cell migration and invasion, potentially in extensive cancer types, including breast, bladder and liver cancer. The present study is, to the best of our knowledge, the first to identify linc-ITGB1 as a critical mediator of cell proliferation, migration and invasion in HCC cells.

The mechanism(s) by which linc-ITGB1 promotes cell proliferation, migration and invasion in HCCLM3 cells remain unknown. The data of the current study indicates that a knockdown of linc-ITGB1 arrested cell cycle progression in the G0/G1 phase. Considering that this cell cycle arrest, specifically in the G0/G1 phase, links HCCLM3 cells to apoptosis $(28,29)$. Deregulation of cell cycle progression is a hallmark of tumor growth (30). It is possible that linc-ITGB1 contributes to cell proliferation by controlling cell cycle progression and inducing cell apoptosis. This hypothesis was supported by a study that reported the deregulation of cell 
cycle key regulators by knockdown of linc-ITGB1 (21). In addition, the mechanisms of how linc-ITGB1 mediates cell migration and invasion remains largely unknown. Currently, the available data indicates that the epithelial-to-mesenchymal transition (EMT) process is involved in linc-ITGB1-mediated cell migration and invasion in breast and gallbladder cancer $(20,21)$. However, details on the regulation of EMT by linc-ITGB1 are yet to be elucidated. Furthermore, the name of linc-ITGB1 suggests that the gene B1-integrin may be co-regulated by linc-ITGB1. How these regulatory networks collectively contribute to linc-ITGB1-mediated aggressive activities remains to be elucidated in HCC.

In conclusion, the present study has, to the best of our knowledge, been the first to introduce a novel lncRNA linc-ITGB1, which promotes cell proliferation, migration and invasion in HCC. The data of the current study suggests that a knockdown of linc-ITGB1 may be a promising therapeutic strategy to treat HCC. However, the underlying detailed mechanisms remains to be elucidated.

\section{References}

1. Ferlay J, Shin HR, Bray F, Forman D, Mathers C and Parkin DM: Estimates of worldwide burden of cancer in 2008: GLOBOCAN 2008. Int J Cancer 127: 2893-2917, 2010.

2. Jemal A, Bray F, Center MM, Ferlay J, Ward E and Forman D: Global cancer statistics. CA Cancer J Clin 61: 69-90, 2011.

3. Perz JF, Armstrong GL, Farrington LA, Hutin YJ and Bell BP: The contributions of hepatitis $B$ virus and hepatitis $C$ virus infections to cirrhosis and primary liver cancer worldwide. J Hepatol 45: 529-538, 2006.

4. Wu YH, Ai X, Liu FY, Liang HF, Zhang BX and Chen XP: c-Jun $N$-terminal kinase inhibitor favors transforming growth factor- $\beta$ to antagonize hepatitis B virus $X$ proteininduced cell growth promotion in hepatocellular carcinoma. Mol Med Rep 13: $1345-1352,2016$

5. Fong ZV and Tanabe KK: The clinical management of hepatocellular carcinoma in the United States, Europe, and Asia A comprehensive and evidence-based comparison and review. Cancer 120: 2824-2838, 2014.

6. van Malenstein H, van Pelt J and Verslype C: Molecular classification of hepatocellular carcinoma anno 2011. Eur J Cancer 47: 1789-1797, 2011

7. De Minicis S, Marzioni M, Benedetti A and Svegliati-Baroni G: New insights in hepatocellular carcinoma: From bench to bedside. Ann Transl Med 1: 15, 2013.

8. Batista PJ and Chang HY: Long noncoding RNAs: Cellular address codes in development and disease. Cell 152: 1298-1307, 2013.

9. Rinn JL and Chang HY: Genome regulation by long noncoding RNAs. Annu Rev Biochem 81: 145-166, 2012.

10. Huarte $M$ and Rinn JL: Large non-coding RNAs: Missing links in cancer? Hum Mol Genet 19: R152-R161, 2010.

11. Gupta RA, Shah N, Wang KC, Kim J, Horlings HM, Wong DJ, Tsai MC, Hung T, Argani P, Rinn JL, et al: Long non-coding RNA HOTAIR reprograms chromatin state to promote cancer metastasis. Nature 464: 1071-1076, 2010.
12. Mourtada-Maarabouni M, Pickard MR, Hedge VL, Farzaneh F and Williams GT: GAS5, a non-protein-coding RNA, controls apoptosis and is downregulated in breast cancer. Oncogene 28: 195-208, 2009

13. Redis RS, Sieuwerts AM, Look MP, Tudoran O, Ivan C, Spizzo R, Zhang X, de Weerd V, Shimizu M, Ling H, et al: CCAT2, a novel long non-coding RNA in breast cancer: Expression study and clinical correlations. Oncotarget 4: 1748-1762, 2013.

14. Gutschner T, Hämmerle M, Eissmann M, Hsu J, Kim Y, Hung G, Revenko A, Arun G, Stentrup M, Gross M, et al: The noncoding RNA MALAT1 is a critical regulator of the metastasis phenotype of lung cancer cells. Cancer Res 73: 1180-1189, 2013.

15. Liu Q, Huang J, Zhou N, Zhang Z, Zhang A, Lu Z, Wu F and Mo YY: LncRNA loc285194 is a p53-regulated tumor suppressor. Nucleic Acids Res 41: 4976-4987, 2013.

16. Xia T, Liao Q, Jiang X, Shao Y, Xiao B, Xi Y and Guo J: Long noncoding RNA associated-competing endogenous RNAs in gastric cancer. Sci Rep 4: 6088, 2014.

17. Tsai MC, Spitale RC and Chang HY: Long Intergenic Noncoding RNAs: New links in cancer progression. Cancer Res 71: 3-7, 2011.

18. Gloss B, Moran-Jones K, Lin V, Gonzalez M, Scurry J, Hacker NF, Sutherland RL, Clark SJ and Samimi G: ZNF300P1 Encodes a lincRNA that regulates cell polarity and is epigenetically silenced in type II epithelial ovarian cancer. Mol Cancer 13: 3, 2014

19. Kim K, Jutooru I, Chadalapaka G, Johnson G, Frank J, Burghardt R, Kim S and Safe S: HOTAIR is a negative prognostic factor and exhibits pro-oncogenic activity in pancreatic cancer. Oncogene 32: 1616-1625, 2013.

20. Wang L, Zhang Y, Lv W, Lu J, Mu J, Liu Y and Dong P: Long non-coding RNA Linc-ITGB1 knockdown inhibits cell migration and invasion in GBC-SD/M and GBC-SD gallbladder cancer cell lines. Chem Biol Drug Des 86: 1064-1071, 2015.

21. Yan M,Zhang L, Li G, Xiao S, Dai J and Cen X: Long non-coding RNA linc-ITGB1 promotes cell migration and invasion in human breast cancer. Biotechnol Appl Biochem 64: 5-13, 2017.

22. Livak KJ and Schmittgen TD: Analysis of relative gene expression data using real-time quantitative PCR and the 2(-Delta Delta C(T)) Method. Methods 25: 402-408, 2001.

23. Ge Z, Zhang B, Bu X, Wang Y, Xiang L and Tan J: Molecular mechanism of activating protein-4 regulated growth of hepatocellular carcinoma. Tumor Biol 35: 12441-12447, 2014.

24. Wang J, Su H, Han X and Xu K: Inhibition of fibroblast growth factor receptor signaling impairs metastasis of hepatocellular carcinoma. Tumor Biol 35: 11005-11011, 2014.

25. Tian GY,Zang SF, Wang L, Luo Y, Shi JP and Lou GQ: Isocitrate dehydrogenase 2 suppresses the invasion of hepatocellular carcinoma cells via matrix metalloproteinase 9. Cell Physiol Biochem 37: 2405-2414, 2015.

26. Wang LH: Molecular signaling regulating anchorage-independent growth of cancer cells. Mt Sinai J Med 71: 361-367, 2004.

27. Thullberg M and Strömblad S: Anchorage-independent cytokinesis as part of oncogenic transformation? Cell Cycle 7: 984-988, 2008.

28. Xu XY, Xia P, Yu M, Nie XC, Yang X, Xing YN,Liu YP, Takano Y and Zheng HC: The roles of REIC gene and its encoding product in gastric carcinoma. Cell Cycle 11: 1414-1431, 2012

29. Li X, Cheung KF, Ma X, Tian L, Zhao J, Go MY, Shen B, Cheng AS, Ying J, Tao Q, et al: Epigenetic inactivation of paired box gene 5, a novel tumor suppressor gene, through direct upregulation of $\mathrm{p} 53$ is associated with prognosis in gastric cancer patients. Oncogene 31: 3419-3430, 2012.

30. Sherr CJ: Cancer cell cycles. Science 274: 1672-1677, 1996. 